\title{
LEGAL ASPECTS OF CANADIAN TRADE WITH THE PEOPLE'S REPUBLIC OF GHINA
}

\author{
Tung-PI CheN*
}

\section{INTRODUCTION}

Canada's economic well-being depends vitally upon foreign trade, which accounts for nearly fifty per cent of its gross national product. Traditionally, this important sector of the national economy has relied predominantly on the United States and British markets. The recent American surcharge on imports, together with Britain's entry into the Common Market, have accelerated Canadian efforts to search for alternative markets in Asia, including China. ${ }^{1}$

Sino-Canadian trade relations have a relatively long history, going back to the last century, when Canada imported Chinese laborers to construct its transcontinental railway. But the overall volume of trade remained small until the 1950's, when the United States imposed an embargo on strategic trade with China. The breakthrough came in 1961, when China began its mass wheat purchases from Canada. ${ }^{2}$ By 1971, Canada had become China's fourth most important trading partner (after Japan, Hong Kong, and West Germany) with a total trade volume of U.S. $\$ 277$ million. $^{3}$ It is expected that Canadian exports to, and imports from, China for 1973 will surpass the record levels reached in 1972 , when two-way trade totaled over $\$ 300$ million. ${ }^{4}$

Over the years Canadian sales to China in addition to wheat have included raw materials, semi-finished products, chemicals, and advanced electronics, transport, mining and agricultural equipment. But since 1961 wheat, the backbone of the prairie economy, has always been the dominant commodity, accounting for about ninety per cent of Canadian exports to China. It is because of the wheat sales that the bilateral trade balance has been overwhelmingly in Canada's favor. In 1972, for example, China ran a $\$ 210$ million trade deficit with Canada, and for 1973 the deficit could reach $\$ 250$ million. Although the absolute volume of Sino-Canadian trade is relatively small, ${ }^{5}$

\footnotetext{
*Associate Professor of Law, Queen's University, Canada.

1 That it has been Canada's policy to develop trade and friendly relations with the "Pacific Rim" countries, see Hon. Mitchell Sharp, Foreign Policy for Canadians: Pacific (Ottawa, Dep't of External Affairs, 1970) (a foreign policy white paper for the government of Canada).

2 This breakthrough resulted from a series of coincidences: three successive years of bad harvests in China followed by the Sino-Soviet break; a huge wheat surplus in Canada; and a strongwilled Canadian Prime Minister, John G. Diefenbaker, who had been elected from the wheat-growing prairies.

${ }^{3}$ See Godson, China Makes Economic Progress, Canada Commerce, Mar. 1973, at 2, 6. Hereinafter, all dollar references are to U.S. dollars.

4 See Press Statement of Canadian Prime Minister Pierre Elliot Trudeau in Peking on October 13, 1973, in Dep't of External Affairs, Statements and Speeches No. 73/20 (1973).

In a good year, such as 1968, sales to China barely exceeded 1 per cent of Canadian exports, while imports from China were less than 0.2 per cent of Canada's total imports. Canada's share of
} 
it is thus very important to the Canadian economy and to its trade balance generally.

Sino-Canadian trade has been conducted within a legal framework, including specific contracts, trade agreements, the domestic law of both countries and, until recently, laws of the United States. Since there is no dearth of literature depicting the legal structure of China's foreign trade, that topic will not be discussed here. ${ }^{6}$ Rather, this article will examine (1) Sino-Canadian commercial agreements, (2) Canadian export and import controls, and (3) contracting practices.

\section{I}

\section{Sino-Canadian Commercial Agreements?}

Since they recognized each other's government in 1970, Canada and China have concluded a series of bilateral agreements which constitute the basis for commercial relations between the two countries. The most important of these is the 1973 Trade Agreement ${ }^{8}$ which was signed in Peking by the Canadian Prime Minister, Mr. Pierre Elliot Trudeau. The Agreement, which has a term of three years, is a relatively simple document consisting of eleven articles. It provides for the reciprocal granting of most-favorednation (MFN) status, sets forth the types of currencies to be used for payments, provides for certain assurances of easier access by businessmen to each other's markets, and establishes a Joint Trade Committee to monitor implementation of the Agreement. ${ }^{9}$ The major features of the Agreement, with the exception of the currency provisions, will be examined in this section. Currency matters will be taken up in the discussion of contractual terms relating to payments.

\section{A. MFN Treatment}

Both Canada and China employ the most-favored-nation clause as a fundamental principle of their trade treaties and agreements. Thus, in article 2 of the Sino-Canadian Trade Agreement, each side promises to extend MFN status to products of the other with regard to "customs duties, all taxes and subsidiary charges ... as well as to other relevant formalities, regulations and procedures." However, article 3 makes clear that article 2 does not apply to preferences granted by either government to neighboring

China's trade has been somewhat more important, but is still only around a 5 to 6 per cent level. See S.P.S. Ho \& R. W. Huenemann, Canada's Trade With China: Patterns and Prospects 11 (1972).

${ }^{6}$ For useful discussions of the topic, see Cohen, Chinese Law and Sino-American Trade, in CHINA Trade Prospects and U.S. Policy (A. Eckstein ed. 1971); Hsiao, Communist China's Foreign Trade Organization, 20 VAND. L. REV. 303 (1967).

${ }^{7}$ For a general discussion of China's foreign trade agreements, see Hsiao, Communist China's Trade Treaties and Agreements (1949-64), 21 VAND. L. REv. 623 (1968).

8 Trade Agreement Between Canada and the People's Republic of China (mimeo, Oct. 13, 1973).

${ }_{9}$ The Sino-Canadian Trade Agreement seems to follow the same pattern as that established by China's recent trade pacts with Australia and Japan. For brief reports on these pacts, see FAR Eastern Econ. Rev., Aug. 6, 1973, at 29; id., Sept. 10, 1973, at 45. 
countries to facilitate border trade or as a result of participation in a customs union, a free trade area such as the Canada-United States Auto Pact, ${ }^{10}$ or other such arrangements. Examples of the last category would be privileges granted as a result of the British Preferential Tariff ${ }^{11}$ and under the resolution adopted by the 1968 United Nations Conference on Trade and Development to developing countries. ${ }^{12}$ In addition, there is a broad exception in article 9 which permits either country to take restrictive measures to protect "national security and economic interests, human, animal and plant life or health, and... national historical relics." Existing Canadian controls on strategic exports, quotas, anti-dumping and countervailing duties, and health and safety regulations regarding imports are therefore fully preserved by article $9 .{ }^{13}$

It is questionable, however, whether the MFN clause in the Trade Agreement will have a significant effect on future trade between the two countries. Even before the conclusion of the Trade Agreement, Peking's exports to Canada had always enjoyed MFN treatment under a modus vivendi entered into between Canada and Nationalist China in 1946. ${ }^{14}$ Moreover, since Canada grants the British Preferential Tariff to all British Commonwealth Countries $^{15}$ and extends MFN treatment to almost all other countries (including the U.S.S.R. and a number of other communist countries), ${ }^{16}$ Chinese goods will not, as a result of the MFN clause, gain a competitive advantage in Canadian markets. ${ }^{17}$ For Canada, MFN treatment by the Chinese will also be of limited value. China is a country with a centrally planned economy. The state controls imports and exports, and determines types, assortment, origin, and distribution of goods. Thus, the reciprocal reduction of tariffs under the MFN clause by China may not achieve an increase in export opportunities for Canadian firms as an MFN clause is generally intended to do. ${ }^{18}$

${ }^{10}$ Automobile Products Agreement with Canada, Jan. 16, 1965, [1966] 1 U.S.T. 1372, T.I.A.S. No. 6093; [1966] Can. T.S. No. 14.

${ }_{11}$ The British Preferential Tariff is extended to countries forming the British Commonwealth of Nations. The names of these countries are listed in the Customs Tariff Act, Can. Rev. Star. c. C-41, $\$ 3(2)(1970)$. The tariff rates are set forth in Schedule A of the same Act.

12 U.N. CTAD Resolution 21(II) (Mar. 26, 1968), U.N. Conference on TRADE AND Development, Report of the Conference on Its Second Session With Related Documents. CMnd. No. 3649, at 74 (1968) (presented to Parliament by the President of the Board of Trade).

13 Problems concerning Canada's export and import controls on Sino-Canadian trade will be discussed in Part II, infra (Canadian Export and Import Controls).

${ }^{14}$ Exchange of Notes Between Canada and China Constituting a Commercial Modus Vivendi Between the Two Countries, Sept. 26, 1946, [1946] Can. T.S. No. 37.

15 Even after Britain's entry into the EEC, the Customs Tariff Act, Can. Rev. STAT. c. C-41 (1970), has yet to be amended to terminate the application of the British Preferential Tariff to British goods.

${ }_{16}$ The communist countries which enjoy MFN treatment by Canada are Czechoslovakia, Hungary, Romania, the U.S.S.R., and Yugoslavia. See McGoldrick's Canadian Customs and EXCISE TARIFFs 1973-74, at 100-02 (1973).

${ }_{17}$ China's main competitors in Canadian markets are Hong Kong and Taiwan, and both enjoy MFN treatment by Canada. Hong Kong is one of the few Commonwealth political entities not granted Preferential Tariff concessions by Canada. Taiwan continues to receive MFN treatment by Canada even though Canada has breached diplomatic relations with the government of Nationalist China.

${ }^{18}$ For discussions of the futility of the MFN clause in economic relations between market economies and planned economies, see S. Pisar, Coexistence and Commerce: Guidelines for Trans- 
However, since in the Sino-Canadian Trade Agreement the most-favorednation principle is applied not only to tariffs but also to "formalities, regulations and procedures," it may at least serve to protect Canadian traders from other discriminatory measures by the Chinese bureaucracy. Perhaps articles 1 and 6 , which require the contracting parties to "endeavor to create favorable conditions" for trade and to "facilitate (in accordance with their import and export requirements and possibilities) the development of ... long-term commercial arrangements," may prove to be more significant for the future expansion of commerce between the two countries.

\section{B. Easier Access to China for Canadian Businessmen}

One of the most important achievements of the Trade Agreement is its facilitation of business contacts between the two countries. Thus, in article 7, both sides "undertake to promote the interchange of persons, groups and delegations engaged in trade." During the negotiations, the two parties further agreed that a program of such interchanges would be established in the near future. ${ }^{19}$

In the past, a major complaint of Canadian businessmen has been the number of practical obstacles encountered in conducting trade with China. Thus no Canadian company except Canadian Pacific Air (CP Air) has been permitted to establish a formal resident office in China for the purpose of market investigation and product promotion, ${ }^{20}$ nor have Canadian companies been able to engage Chinese government corporations as agents to carry out commercial activities in China. The means for business contacts between Canadian traders and Chinese state trading corporations are still confined largely to the use of correspondence and to face-to-face negotiations at the semiannual Canton Trade Fair. ${ }^{21}$ Direct negotiations outside the Fair, through the exchange of trade delegations, are now becoming more frequent, and occasionally when the Chinese have a serious interest in a particular product, Canadian businessmen are invited to Peking for talks with the Chinese trading corporations. ${ }^{22}$

Nevertheless, the Chinese continue to display a marked preference for restricting their main dealings with noncommunist countries to the semiannual Ganton Trade Fair. When correspondence is used, moreover, some

actions Between EAst and West 195-98 (1970); Domke \& Hazard, State Trading and the MostFavored-Nation Clause, 52 AM. J. INT'L L. 55, 67-68 (1958). See also Pisar, Coexistence and Commerce With Russia and China: Ground Rules for East-West Trade, in CuRRENT Legal Aspects of Doinc Business With Sino-Soviet Nations 1, 5 (J. Haight ed. 1973).

19 See note 4 supra.

${ }^{20} \mathrm{By}$ the terms of article 13 of the Sino-Canadian Air Transport Agreement, CP Air, as the designated Canadian airline to fly to China, is specially permitted to establish a resident office in China "to station representatives and staff required for the operation of the agreed services." See note 24 infra.

21 For a first-hand account of the Fair, see Klingenberg, The Canton Trade Fair: The Initiation of United States-Chinese Trade, 13 VA. J. INT'L L. 63 (1972). For a Canadian experience at the Fair, see Kaufman, Come to the Fair, Foreign Trade, Oct. 1970, at 11 (Spec. Supp.).

22 Another opportunity for mutual business contacts was provided by the two solo trade exhibitions held in the fall of 1972-one for Canadian goods in Peking and the other for the Chinese in Toronto. See Toronto Globe and Mail, Aug. 15, 1972, at 8, col. 1; id., Sept. 16, 1972, at 27, col. 1. 
Canadian businessmen have been perturbed by the fact that once they have made a detailed offer to the Chinese at great expense, they often receive only a terse reply, if any at all, without any explanation of what was unsatisfactory about the offer ${ }^{23}$ It is hoped that improved opportunities for Canadian businessmen to conduct their affairs in China as provided for in the Trade Agreement will lessen these difficulties.

\section{Joint Trade Committee}

The most concrete achievement of the Trade Agreement is perhaps article 8, which provides for the establishment of a Joint Trade Committee "to facilitate the implementation" of the Agreement. The provision calls for meetings at least once each year, to be held alternately in Peking and Ottawa. When necessary, special meetings may also be arranged to discuss matters of mutual interest.

The Committee will be very useful in many respects. The yearly intergovernmental consultation will provide an effective means for solving problems which might otherwise hamper expansion of trade between the two countries. Should the Chinese exports cause or threaten to cause disruption in Canada's domestic market, the Committee could serve as a convenient and useful forum for direct negotiation in order to find ways to either prevent or remedy the situation. Above all, Canadian officials will be able through such meetings to obtain official information on China's import priorities and export possibilities, and thus be in a position to organize visits by Canadian trade missions in the fields mentioned by the Chinese.

\section{Other Trade Agreements}

In addition to the general Trade Agreement, Canada and China also concluded two other trade-related agreements in 1973-one on air transport $^{24}$ and the other concerning reciprocal trademark registration. ${ }^{25}$

\section{Air Transport Agreement}

The Sino-Canadian Air Transport Agreement, which follows the general pattern of China's civil aviation agreements with noncommunist countries, ${ }^{26}$ is consistent with many of the Chicago Convention principles. ${ }^{27}$ In the

\footnotetext{
${ }^{23}$ See Cutler, China Wants Only Those Visitors Who Are Useful, Financial Post, Nov. 3, 1973, at 7 , col. 1.

24 Civil Air Transport Agreement Between Canada and the People's Republic of China, signed at Ottawa, June 11, 1973, and entered into force on the same date (mimeo, 1973) [hereinafter referred to as Air Transport Agreement].

${ }^{25}$ Exchange of Notes Between Canada and the People's Republic of China Constituting an Agreement Concerning Reciprocal Registration of Trade Marks, signed at Peking, July 16, 1973, and entered into force on the same date (mimeo, 1973).

${ }^{26}$ Since China is not a party to any multinational civil aviation convention except the Warsaw Convention of 1929 , which it accepted in 1958, China relies on a series of bilateral aviation agreements as the legal basis of its international civil air transport. For an excellent discussion of China's civil air transport agreements, see King \& Roosevelt, Civil Aviation Agreements of the People's Republic of China, 14 HARV. J. INT'L L. 316 (1973).

${ }^{27}$ Convention on International Civil Aviation, signed at Chicago, Dec. 7, 1944. 61 Stat. 1180, T.I.A.S. No. 1591, 15 U.N.T.S. 295.
} 
Agreement, each contracting party grants to the other rights of transit across its territory, discharge of passengers and freight in its territory, and embarkation of passengers and freight within its territory ${ }^{28}$ These are known as the first, third, and fourth of the "five freedoms" of international civil aviation. ${ }^{29}$ Although there is no mention of the second freedom-the freedom of landing for non-traffic technical purposes-article 8 of the Agreement expressly requires aiding each other's aircraft when in distress. This seems to grant a restricted version of the second freedom. With respect to the fifth freedom-the right of carriage of traffic between the territory of the other contracting party and a third country-it has been agreed to leave this to future negotiation between the aviation authorities of the two countries. ${ }^{30}$ The traffic right expressly excluded is the right to cabotage along the designated routes in the territory of the other contracting party. The exclusion is apparently designed to protect the embryonic Chinese airline, the General Administration of Civil Aviation of China (GACAC), from Canadian competition. ${ }^{31}$

Pursuant to the Air Transport Agreement, the Canadian Department of Transport and GACAC have signed a supplementary technical Protocol setting out detailed arrangements related to the operation of the agreed air services. ${ }^{32}$ By the same authorization and with the approval of civil aviation authorities of the two countries, CP Air and the Department of International Affairs of GACAC (the two airlines designated by the contracting parties) have concluded a commercial agreement prescribing the tariff, frequency, and capacity for air services by the two airlines. ${ }^{33}$ As a result of these aviation agreements, China's designated carrier will be able to operate flights between China, Vancouver, and Ottawa. CP Air will operate services between Canada, Shanghai, and Peking. ${ }^{34}$ The air link thus established will improve business contacts and increase exchange of goods between the two countries.

\section{Reciprocal Trademark Registration}

The Reciprocal Trademark Registration Agreement took the form of an

${ }^{28}$ The "five freedoms" are contained in the International Air Transport Agreement, opened for signature Dec. 7, 1944, 59 Stat. 1701, E.A.S. No. 469, 171 U.N.T.S. 387.

${ }^{29}$ Air Transport Agreement, Annex, art. II (1), (2), \& (3).

${ }^{30}$ Id. art. 15.

${ }^{31}$ Id., Annex, art. 15.

32 Protocol Between the Department of Transport of Canada and the General Administration of Civil Aviation of China Concerning Technical Requirements and Procedures Related to the Operation of the Agreed Air Services, signed and entered into force on June 11, 1973 (mimeo, 1973).

${ }^{33}$ Air Transport Agreement, arts. 7, 8, \& 13. See also Toronto Globe and Mail, Oct. 16, 1973, $\S \mathrm{B}$, at 6 , col. 1 .

${ }^{34} \mathrm{CP}$ Air is expected to commence air service to China as soon as the transit and refueling arrangements with the Japanese authorities have been worked out. The Japanese are, however, reported to be reluctant to grant these concessions to CP Air before Japan itself has established an air link with China. See Toronto Globe and Mail, Nov. 10, 1973, § B, at 3, col. 7. Meanwhile, despite the rights granted by the Air Transport Agreement, the Chinese airline is not expected to commence service to Canada in the near future. See id., May 20, 1972, at 12, col. 5. 
exchange of notes signed on July 16, 1973..$^{35}$ The Agreement provides that "persons, partnerships, companies, corporations and governmental enterprises of either country may apply for registration of trademarks in the other country in accordance with its law and be granted the right to exclusive use thereof." Thus, a Canadian company may now apply to the Chinese authorities, namely the Central Administration of Industry and Commerce (CAIC) ${ }^{36}$ for registration of a trademark if the trademark is already duly registered under the name of the company in Canada under the Trade Marks Act. $^{37}$ Under Chinese regulations, the duration of the right to exclusive use of the foreign trademark is to be determined at the discretion of the CAIC. ${ }^{38}$ Likewise, a Chinese state enterprise may register its trademark in Canada, although no such registration is necessary for the protection of trademarks under Canadian common law.

China does not have patent law as it is known in the West. ${ }^{39}$ The lack of patent protection in China does not, however, constitute a significant impediment to Sino-Canadian trade. In fact, during the 1972 Canadian Trade Exposition in Peking, many Canadian exhibitors sold their sample items of electronics and telecommunication equipment which had been on display, although it was known that the Chinese purchased such sophisticated equipment for imitation purposes. Probably correctly, these Canadian businessmen were of the opinion that there were practical limits to the plagiarism of modern technology. Moreover, it would be far cheaper for China to continue importing these sophisticated items than for it to try to meet its own needs with domestic copies which might become obsolete by the time they are manufactured. In any case, foreign exporters of modern technological goods who wish to prevent the Chinese from copying can always insist on such a clause in the contract of sale.

\section{E. Related Agreements}

In addition to the above-mentioned commercial agreements, there is another series of bilateral agreements between Canada and China which will facilitate the movement of persons between the two countries. Among these are agreements on exchanges in cultural, sports, medical sciences, health care, and scientific fields. Most important are agreements on consular affairs, which include understandings in three areas. The broadest of these is an understanding concerning the formal establishment of consular relations between the two countries to be conducted "in accordance with the general principles and practice of international law." Included in the understanding is a provision calling for each side to set up a consulate general in the other country-the Chinese in Vancouver and the Canadians in either Canton or Shanghai. ${ }^{40}$

\footnotetext{
35 See note 25 supra.

${ }^{36}$ For a general discussion of registration of foreign trademarks in China, see Hsiao, Communist China's Foreign Trade Organization, 20 VAND. L. REv. 303, 317-18 (1967).

${ }^{37}$ Can. Rev. Stat. c. T-10 (1970).

${ }^{38}$ See note 36 supra.

${ }^{39}$ See Pan American World Airways, Trade With China 78-79 (1971).

${ }^{40}$ Consular Understanding Between Canada and the People's Republic of China, in the form
} 
The other two understandings concern the simplification of visa procedures and the reunification of families. ${ }^{41}$ While all these agreements are not strictly trade-related, they can be seen as steps necessary to provide a suitable background for trade.

Last, but not least, is the problem concerning Canada's international claims against China for losses resulting from Peking's nationalizations and other takings of Canadian properties after October 1, 1949. So far only the "Ming Sung claim" has been settled. ${ }^{42}$ Yet to be resolved is Canada's official claim with respect to its former embassy in Nanking and an unknown number of private claims. (The Canadian government is presently in the process of identifying the number of such private claims and the volume of losses involved.) An agreement between the two countries to settle these outstanding claims is necessary if a potential impediment to trade is to be avoided.

\section{II}

\section{CANADIAN EXPORT AND IMPORT CONTROLS}

The principal Canadian legislation for the control of exports is the Export and Import Permits Act, ${ }^{43}$ which is administered by the Department of Industry, Trade, and Commerce. ${ }^{44}$ This Act gives the government basic authority to deny exports to communist countries when such exports are considered to be detrimental to the security of Canada.

of an exchange of notes signed in Peking on Oct. 24, 1973 (mimeo, 1973).

- ${ }^{41}$ Understanding on Reunion of Families Between Canada and the People's Republic of China, in the form of an exchange of notes signed in Peking on Oct. 24, 1973.

${ }^{42}$ The agreement settling the "Ming Sung claim" took the form of an exchange of notes. See Exchange of Notes Between Canada and the People's Republic of China Settling and Terminating the Loans Contracted by the Ming Sung Industrial Co., Ltd., from the Canadian Banks on October 30,1946 , signed and entered into force on June 4,1973 (mimeo, 1973). The claim arose out of a loan obtained by the Chinese Ming Sung Industrial Company in 1946 from three Canadian banks to finance construction of nine vessels by two Canadian companies. The loan was guaranteed by the Canadian government. The vessels were built and delivered to the Chinese company in 1949. After the establishment of the Peking government in the same year, the Ming Sung Company was nationalized and was prevented from making the payments pursuant to the terms of the loan. Therefore, pursuant to the terms of the guarantee, the Canadian government had to pay approximately $\$ 14.5$ million to the Canadian banks between 1951 and 1960 . In settling the claim, the Chinese government agreed to repay the full amount, without interest. See Dep't of External Affairs, Press Release No. 54 (June 4, 1973). For a discussion of the general practice with regard to Canadian international claims, see Copithorne, State Responsibility and International Claim (mimeo, Dep't of External Affairs, 1972).

33 Can. Rev. Stat. c. E-17, as amended (1970).

44 There are, in addition, export controls over various specialized goods administered by other governmental departments and agencies. These specialized goods and the controlling agencies include: radioactive materials, Atomic Energy Control Board, pursuant to the Atomic Energy Control Act, Can. Rev. STat. c. A-19 (1970); gold, Department of Finance, pursuant to the Gold Export Act, CAN. Rev. Stat. c. C-12 (1970); narcotic drugs and marijuana, Department of Justice, pursuant to the Narcotic Control Act, Can. Rev. Stat. c. N-1 (1970); oil, gas, and power, National Energy Board, pursuant to the National Energy Board Act, CaN. REv. Stat. c. N-6 (1970); vessels, Department of Transport, pursuant to the Canada Shipping Act, Can. Rev. STAT. c. S-9 (1970); wheat, oats, and barley, Canadian Wheat Board, pursuant to the Canadian Wheat Board Act, Can. Rev. Stat, c. C-12 (1970); and certain agricultural commodities, various marketing boards, pursuant to the Farm Products Marketing Agencies Act, CAN. STAT. c. C-65 (1970-72). 
Under section 3 of the Act, the Governor in Council is authorized to establish an Export Control List, ${ }^{45}$ chiefly for the purpose of regulating strategic trade. The Act also provides for the maintenance of an Area Control List, including therein "any country the export of any goods to which he [the Governor in Council] deems it necessary to control."46 Pursuant to the Act, every export (to any country in the world except the United States) of goods included in the Export Control List, or every shipment of goods (whether included in the Export Control List or not) to any country named in the Area Control List, requires an Export Permit. ${ }^{47}$ Since China is a country included in the Area Control List, ${ }^{48}$ all sales to that country are subject to the Export Permit requirement unless the goods are those which can be exported under a general authorization known as a General Export Permit. ${ }^{49}$

Because of the vital importance of exports to its economic well-being, ${ }^{50}$ Canada has always followed policies designed to minimize restrictions on trade. Thus, in determining whether an Export Permit should be issued under the Export and Import Permits Act for a particular sale to China, the attitude of the Canadian government has regularly been not to go beyond the minimum embargo of strategic trade required by COCOM. ${ }^{51}$ Consequently, if goods destined for China are not of United States origin and are not of a strategic nature prohibited in the COCOM embargo lists, an Export Permit is readily available. Moreover, since throughout the past two decades the COCOM lists have periodically been revised and the number of embargo items steadily reduced, Canadian export controls have long ceased to be an important obstacle to Sino-Canadian trade.

Indeed, until the recent relaxation of the American embargo against China, the chief legal obstacles encountered by Canada in its trade with China did

4 SOR/70-502, 104 Canada GazetTe, pt. II, No. 23, at 1344 (Nov. 17, 1970).

${ }^{46}$ Export and Import Permits Act, CAN. Rev. Stat. c. E-17, as amended, \& 4 (1970). The current Area Control List covers Rhodesia and all communist countries except Yugoslavia. See SOR/70-501, 104 Canada GazetTe, pt. II, No. 23, at 1343 (Nov. 17, 1970).

$\$ 7$ Can. Rev. Stat. c. E-17, as amended, \& 13 (1970).

${ }^{48}$ See note 46 supra.

49 Section 6 of the Export Permit Regulations, SOR/54-200, 88 Canada Gazette, pt. II, No. 12 (May 27, 1954), 2 Statutory Orders and Regulations 1221 (Consolidation, 1955), provides for the issuance of "General Export Permits" authorizing the export of specified goods to all destinations or to specified destinations.

${ }^{50}$ The importance of export trade to Canada's well-being cannot be overemphasized. This is because Canada has a relatively small population (approximately 21 million people), and so specialization and economics of scale can only be obtained through the development of world markets by export trade. Thus, Canada, despite its small population, is the fourth largest trading country in the world, and one out of every five Canadian workers is employed in export-connected industry or trade. See Canadian American Committee, a New Trade Strategy for Canada and the United States (1957). See also B. Wilkinson, Canada's International Trade: An Analysis of Recent TREnds and Patterns (1968).

${ }^{51}$ COCOM is formally known as the International Coordinating Committee on Strategic Trade with Communist Countries. It was formed in 1949 by the United States and her Western allies to coordinate a trade embargo against European communist countries other than Yugoslavia. In 1950, the embargo was extended to China. To this end, COCOM maintains unpublished lists of strategic goods designated as the minimum restraints to be exercised by participating countries. These countries today include Japan and all NATO members except Iceland. For a discussion of COCOM and the China embargo, see Garson, The American Trade Embargo Against Chi$n a$, in China Trade Prospects and U.S. Policy 60-66 (A. Eckstein ed. 1971). 
not come from Canada's own export controls; rather they originated in the extraterritorial application of United States foreign trade regulations. ${ }^{52}$ One such obstacle was created in the U.S. Export Control Act of $1949^{53}$ and its successor, the Export Administration Act of 1969. ${ }^{54}$ These Acts, and the Export Control Regulations promulgated thereunder, ${ }^{55}$ prohibited exports to China of all commodities and unpublished technical data of U.S. origin without a validated license. These restrictions applied not only to exports from the United States but also to all re-exports from a foreign destination, including Canada. For over two decades, with very few exceptions, no validated licenses were issued. While Canada maintains only the minimum trade controls prescribed by COCOM, all Canadian exports to China which involved end-products made of U.S.-origin parts and components or which were manufactured by using restricted U.S. technology, as well as all re-exports of U.S.-origin goods, were effectively blocked by the United States export controls. ${ }^{56}$ This was true regardless of whether the export was by a Canadian-owned or a U.S.-controlled company, or whether the exports were considered strategic trade according to Canadian law. 57

In the case of Canada's export trade with China, the worst type of legal restraints originating from the United States were created not by the Export Control Act, but by the Foreign Assets Control Regulations ${ }^{58}$ promulgated under the authority of the Trading With the Enemy Act of 1919.59 Basically, these regulations prohibited all resident Americans and all U.S.-controlled subsidiary companies abroad from trading with China (and North Korea and North Vietnam as well) regardless of the origin of the goods involved. ${ }^{60}$ In effect, therefore, all trade between China and U.S.-owned or controlled com-

${ }^{52}$ Comprehensive accounts of the U.S. embargo against China may be found in Berman \& Garson, United States Export Controls-Past, Present, and Future, 67 Colum. L. REv. 791 (1967); Garson, The American Trade Embargo Against China, in China Trade Prospects and U.S. Policy 3 (A. Eckstein ed. 1971); Lee \& McCobb, United States Trade Embargo on China, 1949-70: Legal Status and Future Prospects, 4 N.Y.U.J. INT'L L. \& PoL. 1 (1971); Sommerfield, Treasury Regulations Affecting Trade With the Sino-Soviet Bloc and Cuba, 19 Bus. LAw. 861 (1964).

${ }^{53}$ Act of Feb. 26, 1949, ch. 1, §§ 1-12, 63 Stat. 7 (expired 1969).

5450 U.S.C. App. $\$ \S 2401-13$ (1970). For a discussion of the Act, see Berman, The Export Administration Act of 1969: Analysis and Appraisal, AM. REv. EAST-WEST TrAdE, Jan. 1970, at 19. s5 13 C.F.R. pts. 368-99 (1972).

56 An offender, even a non-resident alien, was subject to criminal sanctions and civil penalties. See Act of Feb. 26, 1949, ch. 1, §§ 1-12, 63 Stat. 7 (expired 1969). See also Export Administration Act, 50 U.S.C. App. $\$ 2406$ (1970). More important than these penalties were the administrative sanctions of warning letters and denial of export privileges available to the U.S. Department of Commerce. Considering the importance of the United States in Canada's international trade, the threat of a cut-off of trade with all American firms was sufficient to deter Canadian traders from violating the U.S. embargo.

${ }^{57}$ In fact, under the Canadian Transshipment Regulations, SOR/55-3, 89 CANADA GazeTtE, pt. II, No. S-1 (Jan. 4, 1955), 2 Staturory Orders aNd Regulations 1243 (Consolidation, 1955), \$ 2; and the Export Control List, SOR/70-502, 104 Canada GazeTte, pt. I, No. 23, at 1344, 1391 (Nov. 17, 1970), re-exports and transshipments from Canada to Area Control List Countries, if they involve goods that originate outside Canada and have not been further manufactured or processed in Canada so as to result in substantial change in value or nature, all require export permits. And the Canadian government, in administering these regulations, has routinely refused to issue export permits if the goods in question contain considerable American content.

${ }^{58} 31$ C.F.R. pt. 500 (1972).

5950 U.S.C. App. $\$ \S 1-44$ (1970).

6031 C.F.R. \$\$ 500.201(b) \& (d), 500.329(a) (1967). 
panies in Canada was subject to a virtually complete embargo.

Indeed, during the 1950's and 1960's the only Canadian exports to China not adversely affected by the American embargo were goods produced by non-U.S.-controlled companies, manufactured without use of U.S.-restricted technology, containing no U.S.-made components, and sold by non-U.S.controlled companies. ${ }^{61}$ Even in industries such as agriculture, where U.S. control was minimal, trade with China was occasionally hindered by American interference. ${ }^{62}$ In fact, it was reported that some Canadian-owned companies voluntarily refrained from even legally permissible dealings with the Chinese for fear of jeopardizing their trading opportunities in the United States. ${ }^{63}$ Although it is impossible to estimate the extent to which Sino-Canadian trade was hampered by the American embargo against China, the close ties between the two North American economies make it clear that the U.S. export controls had a greater impact on Canada than on any other country during the past two decades.

The American embargo was not the only barrier to Sino-Canadian trade, however. An additional complication was China's own reaction to the American trade controls. Throughout the 1960's, the Chinese showed constant reluctance to trade with U.S.-controlled subsidiaries in Canada. In fact, as late as 1971, two years after the beginning of the Nixon thaw, the Chinese had not invited any U.S. subsidiary in Canada to attend the Canton Trade Fair, nor had they expressed any interest in purchasing Canadian products made of U.S.-origin components. This attitude greatly worried Canadian trade officials because, with the exception of agricultural commodities, wood, ferrous metals, semimanufactured products, and communication equipment, most of the goods the Chinese might otherwise be interested in buying from Canada were produced in industries largely controlled by American firms. ${ }^{64}$

These obstacles to Sino-Canadian trade diminished gradually during 1972

${ }^{61}$ Because of the confidential nature of business dealings, it is impossible to identify all Canadian sales and potential sales to China effectively blocked by the Foreign Assets Control Regulations. Some instances have, nevertheless, made headlines. In 1957, the Ford Motor Company in the United States prohibited its Canadian subsidiary to consider a Chinese order of 1,000 trucks. See 1 Parl. Deb., H.C. (Can.) 403 (1958) (speech of Mr. Hazen Argue, M.P.). In the following year, the Aluminum Company of Canada, Ltd. (Alcan), a Canadian corporation owned and controlled in the United States refused to accept a million dollar Chinese order because of the fear of possible violation of the U.S. Foreign Assets Control Regulations. See 1 PARL. DEB., H.C. (Can.) 544 (1959) (speech of Mr. Argue). The Canadian public was disturbed by these events. An excellent discussion on the extraterritoriality of U.S. export controls in Canada may be found in Corcoran, The Trading With the Enemy Act and the Controlled Canadian Corporation, 14 McGill L.J. 174 (1968). See also M. Watkins, Foreign Ownership and the Structure of Canadian Industries 407-10 (Report of the Task Force on the Structure of Canadian Industry, 1968).

62 For example, when Canada began to sell large amounts of wheat to China in 1961, the United States threatened to withhold special loading equipment which could be supplied only by an American subsidiary company in Canada. In addition, for some years the U.S. Government complained to Canada about the easy credit the Canadian Wheat Board extended to the Chinese for their wheat purchases. See H. Albinski, Australian Policies and Attitudes Toward Ghina 294 (1965); P. Lyon, CANAdA in World Afrairs 1961-1963, at 424, 494 (1968).

63 See Financial Post, July 5, 1958, at 1, col. 6.

64 During his visit to Peking in July, 1971, the Honorable Jean-Luc Pépin, the Canadian Minister of 'Trade, spent a substantial amount of time discussing this issue with the Chinese. The outcome was that the Chinese agreed to look at the difficulty "on a case-by-case basis." See N.Y. Times, July 7,1971 , at 3 , col. 5 . 
following the relaxation of the U.S. embargo against China. After having instituted a series of decontrol measures, ${ }^{65}$ the United States Government finally liberalized both the Export Control Regulations ${ }^{66}$ and the Foreign Assets Control Regulations ${ }^{67}$ on February 16, 1972, to reduce the China embargo to the level of restrictions imposed upon the Soviet bloc countries. The effect of this change was to make available to China all commodities now available under general license to the communist countries of Eastern Europe and the Soviet Union, and to permit American-controlled subsidiaries abroad to ship merchandise to China where such shipment is authorized by the host country even if the goods in question could not be exported directly from the United States under the Export Control Regulations.

As is well known, the Chinese responded favorably to the U.S. Government's friendly gesture. In the same month that President Nixon returned from his historic visit to Peking, many U.S. subsidiaries in Canada were invited by the Chinese to the Canton Trade Fair. By the fall of the same year, the assertion that U.S. subsidiaries in Canada were disadvantaged in China trade was finally laid to rest by the events at the Canadian Trade Exhibition in. Peking. Among the more than two hundred Canadian companies represented at the Exhibition, forty were U.S.-controlled. Furthermore, a number of these companies returned to Canada with substantial contracts. ${ }^{68}$ Today, a Canadian company, whether American-controlled or Canadian-owned, may trade with the Chinese, subject only to Canada's controls on strategic trade, free of U.S. institutional restraints (such as a Commodity Control List considerably longer than Canada's Export Control List). ${ }^{69}$ A major source of aggravation between Canada and the United States has thus been removed.

Unlike the export controls, the United States embargo on imports of goods originating from China had little impact on Canada, even before the recent Nixon thaw. ${ }^{70}$ This is because Canadian imports from China in recent years have been dominated by foodstuffs, textiles, and other light industrial goods, ${ }^{71}$

${ }^{65}$ For a step-by-step account of the recent liberalization of U.S. embargo on China trade, see Note, Recent Changes in United States Trade Regulations Affecting the People's Republic of China: A Market Decontrolled. 13 VA. J. InT'L L. 98 (1972).

${ }^{66} 37$ Fed. Reg. 3511 (1972).

${ }^{67}$ Id. at 3520 .

${ }^{68}$ The Chinese even allowed among the exhibitors Dow Chemical of Canada, Ltd., whose U.S. parent manufactures napalm. See Schreiner, Year of the Bull for China Trade, Financial Post, May 6,1972 , at 1 , col. 2. The most lucrative contract signed at the Fair was the $\$ 250,000$ deal secured by R.C.A. (Canada), Ltd., for components to be installed in the ground satellite stations the Chinese. have bought from the U.S. parent company for installation in Peking and Shanghai. See Burns, Canada's Trade Fair at Peking Believed Well Worth Cost, Toronto Globe and Mail, Sept. 8, 1972, $\S \mathrm{B}$, at 1 , col. 3 .

${ }^{69}$ The U.S. Commodity Control List is printed in 15 C.F.R. $\$ 370.2(a)(13)$ (1972). Canada's Export Control List is in SOR/70-502, 104 CANAdA GAzeTte, pt. II, No. 23, at 1344 (Nov. 17, 1970).

${ }_{70}$ Since the U.S. Foreign Assets Control Regulations were amended on December 22, 1969, American-controlled business enterprises abroad have been authorized to deal in merchandise originating in China and to engage in financial transactions with the Chinese. See 31 C.F.R. \$ $500.541(1970)$. On June 10, 1971, the same regulations were further amended by the addition of section 500.547, which permits the import into the United States of all goods of Chinese origin. Thus, Canadian companies, American-controlled or locally-owned, may now re-export such goods into the United States.

${ }^{71}$ Dominion Bureau of Statistics, Exports by Commodities (various years). 
and very few U.S.-controlled Canadian subsidiaries which were subject to the jurisdiction of the U.S. Foreign Assets Control Regulations were engaged in such importation. ${ }^{72}$ Therefore, the legal constraints on Canada's imports from China stem mainly from Canada's internal law. These constraints include customs tariff, anti-dumping, quota, consumer protection, and health or safety provisions.

One barrier which Chinese exports to Canada have had to surmount is that of regular tariffs. As discussed earlier, Chinese commodities enjoy MFN tariffs in Canada, but difficulties may still arise because of Canada's valuation practice. In valuing imports for duty, Canada has traditionally used the fair market value of the imported goods in the exporter's country (the so-called home market value) ${ }^{73}$ Since China is a state trading country with a centrally controlled economy, it is not possible to know the home market value of goods originating there. Thus, following section 30 of the Customs Act, Chinese imports have been valued at the discretion of the Minister of National Revenue. ${ }^{74}$

The method used by the Minister appears quite uncertain at times, and is often believed to be arbitrary. In some cases, the value for duty of British goods has been used in valuing imports from China. ${ }^{75}$ In other cases-especially prior to 1964 , when the textile industry was alarmed about an increase in Chinese textile imports-the Minister of National Revenue resorted to the simple and expedient use of U.S. prices for customs valuation in order to restrict Chinese imports. ${ }^{76}$ In more recent years, however, the Department of National Revenue has used prices from Japan and Hong Kong as "normal" values for customs purposes. ${ }^{77}$ The problem of overvaluation of dutiable Chinese imports has thus subsided.

Anti-dumping is not likely to be a significant obstacle to Canada's imports from China. China is known to have practiced dumping in other countries; ${ }^{78}$ and before the mid-1960's, most Chinese exports to Canada could technically be considered dumping because the import prices of these goods were frequently lower than the value for duty as determined by the Canadian authorities. $^{79}$ But no formal complaint of Chinese dumping in Canada has been

\footnotetext{
${ }^{72}$ For a summary of information on U.S. control in selected industries relevant to SinoCanadian trade, see S.P.S. Ho \& R. W. HuenemanN, supra note 5, at 22-23, table 11 .

${ }_{73}$ The rules for ascertaining and constructing the home market value are set out in sections 36 and 37 of the Customs Act, Can. Rev. Stat. c. C-58 (1970).

${ }^{74}$ Under section $39(\mathrm{a})$, the Minister is authorized to prescribe the manner of determination of duty in any case or class where it "cannot be determined under section 36 or 37 for the reason that like or similar goods are not sold in the country of export or are not sold in such country in the circumstances described in those sections." The ministerial prescription has been held by the Tariff Board to be non-appealable. See H. Bedos \& Co. (Can.), Inc. v. Deputy Minister of National Revenue, 2 Tariff Board Reports 264 (1962).

${ }^{75}$ For example, in H. Bedos \& Co. (Can.), Inc. v. Deputy Minister of National Revenue, 2 Tariff Board Reports 264 (1962), the Tariff Board upheld a ministerial prescription providing that paint brushes imported from China should have their value for duty determined on the basis of the value of similar brushes of United Kingdom origin.

${ }^{76}$ See 1 PARL. Deb., H.C. (Can.) 520 (1959) (statement by Hon. George C. Nowlan, Minister of National Revenue). See also Financial Post, Aug. 10, 1953, at 2, col. 1.

${ }_{77}$ S.P.S. Ho \& R. W. HuENEMANN, supra note 5, at 43 n.79.

${ }^{78}$ See Wilczynski, Dumping and Central Planning, 74 J. Pol. Econ. 250, 256 (1966).

${ }_{79}$ There is a dumping if the export or actual selling price to an importer is less than the duty for value or the normal value of the goods. See Customs Act, CAN. Rev. Stat. c. 58, \& 6(1) (1952);
} 
raised, ${ }^{80}$ perhaps because of the small size of Chinese exports to Canada. Such exports constitute only a tiny fraction of Canada's domestic markets and are thus unlikely to cause injury to Canadian production. ${ }^{81}$

Among Canada's non-tariff barriers to trade, the use of quota restrictions (predominantly on textiles) may prove to be one of the most significant deterrents to the future expansion of Sino-Canadian trade. Although textiles have been China's chief export to Canada, China's share of Canada's textile imports has remained very small. ${ }^{82}$ Despite this fact, Chinese textiles have generated concern and countermeasures in Canada. Thus, since 1963 the Chinese have been asked to sign Voluntary Export Restraint agreements (voluntary quotas) quantitatively restricting such imports. ${ }^{83}$ Moreover, under the authorization of the Textile and Clothing Board Act of 1971, the Canadian government has imposed mandatory quotas on several types of textiles and clothing imports from all sources, including China. ${ }^{84}$

In the past, Canada's actual use of import quotas was relatively unimportant to China trade because Chinese exports to Canada either remained below or right at quota levels. ${ }^{85}$ In the future, however, faced with chronic deficits in trade with Canada and the need to enlarge foreign currency earnings abroad in order to pay for its increasing imports of modern technological products,

Anti-Dumping Act, Can. Rev. STAT. c. A-15, \& 8 (1970).

${ }^{80}$ See Grey, The Development of the Canadian Anti-Dumping System, in Canadian Ant1-Dumping CASES, app. E (1973).

${ }^{81}$ Under Canada's old legislation, an anti-dumping duty would be imposed only when the dumped goods constituted ten per cent or more of the Canadian market, whereas the new AntiDumping Act requires an explicit finding of "material injury" to Canada's domestic production. See Customs Act, Can. Rev. STat. c. 58, \& 6 (1952); General Regulations Under Section 6 of the Customs Act, Order in Council P.C. 1618, July 2, 1956 (Memorandum D51); Anti-Dumping Act, Can. Rev. Stat. c. A-15, §§ 3-5 (1970). Among China's chief exports to Canada, such as textiles, specialty foodstuffs, household utensils, and footwear, it is the textiles category which might threaten to cause injury to Canadian production. However, as will be discussed infra, Canada's textile industry is protected from foreign competition by quota restrictions on imports. For China's chief exports to Canada, see Dominion Bureau of Statistics, Import by Commodities (various years).

${ }_{82}$ For example, in 1969 Canada imported about $\$ 570$ million worth of textiles from all sources, of which about $\$ 11.9$ million came from China (about 2.1 per cent of the total). In 1970 China's share fell to about i.5 per cent. See Dominion BuREau of Statistics, Import by Countries (1970).

${ }^{83}$ See Office of Special Import Policy, Dep't of Industry, Trade, and Commerce, Restraint Arrangements (mimeo, 1973). See also K. StEgEmanN, Canadian Non-Tariff Barriers to Trade 12-13, table 1 (Voluntary Export Restraint Agreements Between Canada and Seventeen Exporting Countries, Jan. 1971) (1972).

${ }^{84}$ The Textile and Clothing Board Act, CAN. STAT. c. 39 (1971), has authorized the government to make additions to the so-called "Import Control List." Products on this list are subject to import licensing in accordance with the provisions of the Export and Import Permits Act, Can. REv. STAT. c. E-17, as amended (1970). Until August, 1971, the Import Control List contained mainly dairy products, coffee, and sugar, which are not among China's chief exports to Canada. See SOR/70-359, 104 CANADA GAZETrE, pt. II, No. 16, at 873 (July 31, 1970). Since then, cotton yarn and men's and boys' shirts have been added to the list. See SOR/71-441, 105 CANADA GAzETTE, pt. II, No. 17, at 1425 (Aug. 26, 1971); SOR/71-539, 105 CANAdA GazeTte, pt. II, No. 17, at 1816 (Oct. 19, 1971). Imports of the former item from China are, however, authorized by a general permit. See General Import Permit No. 4, SOR/71-486, 105 CANADA GaZETTE, pt. II, No. 19, at 1701 (Oct. 1, 1971). The quota of shirts from all sources is expected to be removed by November 30 , 1974. See Dep't of Industry, Trade, and Commerce, News Release No. 2174 (1973).

${ }_{85}$ S.P.S. Ho \& R. W. HuENEMANN, supra note 5 , at 48, table 15 (Canadian Quota Limits and Actual Chinese Exports, Selected Textile Products, 1966-70). 
the Chinese are expected to press hard for larger textile exports to Canada. Canada therefore will either have to accommodate the Chinese demands or face the prospect of a slow-down in China's imports from Canada.

The remaining legal restrictions relevant to imports from China generally involve consumer protection measures designed to protect health and safety. They include the Canada Agricultural Products Standards Act, ${ }^{\mathbf{8 6}}$ the Meat Inspection Act, ${ }^{87}$ the Hazardous Products Act, ${ }^{88}$ the Textile Labelling Act, ${ }^{89}$ and the Consumer Packaging and Labelling Act. ${ }^{90}$ These acts provide the basis for comprehensive inspection requirements and restrictions applicable to the importation of animals and animal products that might transmit diseases of livestock or poultry, the importation and sale of potentially hazardous substances, and the labelling of consumer goods. Since China is a newcomer in the field of foreign trade, these consumer protection measures will continue to give rise to a large number of minor difficulties in Sino-Canadian trade until the P.R.C. manages to familiarize itself with this maze of complex legislation. ${ }^{91}$

III

\section{Contracting Practices}

To date, all of Canada's business deals with the Chinese have been conducted in the form of straight sales, although it is possible that licensing agreements will be used in the future. No direct foreign investment in any form is likely to be admitted in China, as it is in the Eastern European countries. ${ }^{92}$ In sales transactions with China, Canadian trading agencies have not been used extensively. The Chinese prefer to deal directly with Canadian producers or end-users whenever possible, ${ }^{93}$ despite the fact that the Chinese state trading corporations are themselves simply middlemen between domestic producers or users and foreign traders. When middlemen are involved, the Chinese tend to shy away from exclusive dealing arrangements, although a few large Canadian trading companies have been granted exclusive rights because of the perceived value of volume orders and long-term business relationships. ${ }^{94}$

${ }^{86}$ Can. Rev. Stat. C. A-8 (1970).

${ }^{87}$ Id. c. M-7.

${ }^{88}$ Id. c. H-3.

${ }^{80}$ Id., Ist Supp., c. 46.

${ }^{80}$ Can. Stat. c. 41 (1970-72).

${ }^{2}$ See generally IMPORTERs' BuLL., Dec. 5, 1973.

92 The fear of foreign domination, derived from historical experience, is the reason behind this attitude. See Li, Trade With China: A Cautionary Prospectus, in CHINA's TRADE WITH THE WEST: A Political and Economic Analysis 209, 222 (A. Stahnke ed. 1972).

${ }^{83}$ An interesting example was found during the 1972 spring Canton Trade Fair when a large consortium attending the Fair was given a trade discount by a state trading corporation because in this instance the Chinese felt they were dealing with a principal and not an agent. See China Trade REPORT, Apr. 1972, at 5.

${ }^{84}$ This information is based on an interview with an experienced Canadian importer. It was reported that the Chinese refusal to grant exclusivity to certain established buyers to deal in Chinese handicrafts had resulted in a glut on the market in Europe, where supply exceeded demand. See Toronto Globe and Mail, Oct. 16, 1972, at 15, col. 3. Faced with a complaint about similar problems in Canada, a Chinese trade official agreed to make "further study and investigation." See id., Dec. 12, 1973, § B, at 2, col. 2. 
The commercial transactions generally take the form of short-term contracts either concluded by correspondence or made at the Canton Trade Fair once or twice a year depending upon whether the contracts cover the demand for a whole year or for only a six-month period. The major exception to this practice is wheat sales. In wheat sales, the Canadian Wheat Board, which is a Crown agency controlling Canada's wheat exports, does not participate in the Canton Fair. It deals directly with the relevant Chinese state trading corporation (that is, the China National Cereals, Oils, and Foodstuffs Import and Export Corporation) in either Peking or Ottawa. ${ }^{95}$ Except during the period between 1969 and 1972 when one-year contracts were used, all of Canada's wheat sales to China since 1961 have been made under three-year agreements. ${ }^{96}$ Since a long-term wheat agreement is simply a memorandum of intent, ${ }^{07}$ the actual sales are carried out by a second contract negotiated every six months. It is in this contract that the specific terms and conditions of the sale are stipulated. ${ }^{98}$

Individual contracts are of particular importance in Sino-Canadian trade because China does not have an agreement on uniform conditions of trade and delivery with Canada. Unlike Western businessmen, who frequently make contracts orally and accept commercial invoices, bills of lading, and sales receipts as evidence of contractual obligations, the Chinese always require a formal written contract for each transaction. These contracts are usually longer and more detailed than those used by Canadian firms for comparable deals with other Western countries. The form and content of individual contracts, of course, differ in accordance with the nature of the transactions involved. However, except for major transactions, such as the Canadian sales of wheat and satellite communications equipment, the Chinese state trading corporations always insist upon using their standard form contract for both import and export transactions. ${ }^{99}$

There are striking differences between the terms of the Chinese standard contracts of purchase and sale; those differences are invariably favorable to them in providing ample protection for the Chinese state trading corporations. Of course, the addition of new terms or the deletion or alteration of standard terms can be negotiated, and it may be possible to obtain more favorable terms after business relations have been established and Chinese confidence in the foreign trader has been created. ${ }^{100}$ In most cases, however,

\footnotetext{
${ }^{95}$ Before Canada recognized China in 1970 such negotiations were usually held in Hong Kong.

${ }^{96}$ In the near future long-term agreements in other product areas, for example aluminum and woodpulp, also appear likely. See note 4 supra. In fact, as noted earlier, Canada and China mutually pledged in the recent Trade Agreement to "facilitate the development of . . . long-term commercial agreements between the relevant trading bodies and enterprises of the two countries." Trade Agreement Between Canada and the People's Republic of China, art. 6 (mimeo, Oct. 13, 1973).

${ }_{97}$ In a typical long-term wheat agreement, the Chinese party declares its intent to buy, and the Canadian Wheat Board its intent to supply, certain quantities of wheat over a three-year period. The quantities specified are usually a minimum and maximum.

${ }^{98}$ For the Canadian Wheat Board's experience in wheat sales to China, see Kristjanson, Problems and Prospects of Canadian Wheat Sales to China and Russia, 49 J. FARM ECON. 1345 (1967).

${ }^{99}$ Out of well over two dozen non-major contracts seen by this author, only one, dated 1958, was actually drafted by a Canadian businessman who, for that matter, had relied on his own trading experience with the Russians.

${ }_{100} \mathrm{~A}$ Canadian exporter informed the author that in one instance he was able to persuade
} 
Canadian traders have often found it difficult to avoid accepting the Chinese standard terms. As the Chinese negotiators are government officials who are more bureaucrats than businessmen, they tend to be rather rigid in adhering to fixed terms.

As a rule, each contract will contain the commodity name, quantity, specifications, country of origin and manufacture (when the Chinese are the buyers), total value, packing, shipping marks, shipping time, the loading port, and so forth. These business terms are, of course, different in each individual contract. Other important contract terms and conditions which are common in SinoCanadian trade are discussed below.

\section{A. Price Quotation}

Contract unit price terms are usually quoted on an f.o.b. (free on board), c.i.f. (cost, insurance, and freight), or c. \& f. (cost and freight) basis. Chinese imports from Canada are almost always f.o.b. the Canadian port. The Canadian exporter is generally responsible for delivery of the goods on board a Chineseowned or chartered vessel at the port of shipment specified in the contract and usually assumes all risks and costs until delivery is made. Freight is paid and insurance arranged for by the Chinese buyer. Chinese exports to Canada are generally c.i.f. the Canadian port with the Chinese seller assuming responsibility for chartering a vessel or space on a vessel, paying freight costs and insurance, and bearing all risks until the goods are delivered at the Canadian port within a specified time.

The reasons for the Chinese preference for buying f.o.b. and for selling c.i.f. are not difficult to understand. With the existence of a state insurance company, as well as a large fleet of chartered vessels and a growing number of their own, it is natural that the Chinese desire to keep for themselves the profitable business of insurance and shipping. ${ }^{101}$ Occasionally, however, a c. \& $f$. contract of sale may be obtained from the Chinese. Under such a contract, the Chinese state trading corporation is responsible for shipping the goods to the Canadian port of destination, while the Canadian importer may purchase his own insurance. ${ }^{102}$

\section{B. Credit and Payment Terms}

With few exceptions, Sino-Canadian trade dealings are transacted in cash. Since 1968, the Chinese have refused to extend any credit to Canadian im-

his Chinese counterparts to strike out a penalty clause contained in a standard form contract for purchase. According to his account, he was able to do so only because of the friendship and mutual trust he had established with them through many years of dealings.

101 Insurance is handled either by the People's Insurance Company of China or its affiliate, the China Insurance Company, Ltd. Both companies have agents in Canada for processing claims and other matters relating to insurance. Shipping for both import and export is the responsibility of the China National Chartering Corporation. See DeP'T of Industry, Trade, ANd Commerce, MARKeTS For Canadian EXPorters-China 14 (1971).

${ }^{102}$ In one instance of which this writer is aware a Canadian importer was able to buy c. \& $\mathbf{f}$. and to purchase his own insurance because the Chinese refused to sell him an insurance policy covering S.R.C.C. (i.e., strike, riot, and civil commotion) which he required. There was a similar report emanating from the 1972 spring Canton Fair. See China Trade Report, Apr. 1972, at 5. 
porters. ${ }^{103}$ This has certainly reduced Chinese sales to Canada. Presumably the Chinese have been able to sell all they can produce for export. When their production exceeds their present requirements for foreign exchange, they may reconsider credit or time payment. ${ }^{104}$ Thus far, the Chinese have also refused to accept credits from Canada, with the exception of the wheat trade which calls for the extension of short-term credits from the Canadian Wheat Board guaranteed by the government of Canada. ${ }^{105}$ Apparently, the current Chinese leadership is determined to keep the country's dependency on the outside world at a bare minimum. However, as China's industrial needs increase and outside relations improve, it is not unlikely that China might seek, in the near future, medium and long-term credits from Canada for the equipment and technology it would like to buy. ${ }^{106}$

All payments are made by irrevocable letters of credit through the Bank of China (China's foreign exchange bank) and the Canadian chartered banks which have a correspondent relationship with the Bank of China. ${ }^{107} \mathrm{~A}$ comparison of the differences in payment terms would show that, as a rule, when the Chinese are the sellers, the letters of credit opened by the Canadian importers must not only be confirmed, divisible, assignable, and without recourse, but also must be payable as soon as the Chinese present the shipping documents in China to the Bank of China. On the other hand, when the Chinese are the buyers, their letters of credit are not confirmed and are not payable until the Canadian exporters have sent their shipping documents through a Canadian bank to the Bank of China in Peking, and sometimes not even until the goods have arrived and been inspected and approved. ${ }^{108}$ Thus, Canadian exporters are faced with a short period between the dispatch of shipping documents and the receipt of payment by the Bank of China in Peking when they

${ }^{103}$ Before 1968 there were occasions when the Chinese appeared to be willing to extend $\mathrm{D} / \mathrm{P}$ (documents against payment) and 90-day terms, and even to ship on consignment. See Thomson, Selling to Communist China, Foreign Trade, Apr. 18, 1964, at 22, 25.

104 See Endicott, Canada-China Trade and Political Comsiderations, 3 PAcific Communiry 672, 681-82 (1971).

${ }_{105}$ The terms of the contract are a down payment of 25 per cent cash, the balance payable in 18 months with 6 per cent interest.

${ }^{106}$ An eighth state trading corporation, called the China National Technological Import Corporation, was established in the fall of 1972. The corporation is responsible for importation of complete plants, technology, and technological exchanges. The expansion of Sino-Canadian business relations to this area would certainly require sizeable Canadian export credits.

${ }_{107}$ As of 1973, five Canadian banks (the Royal Bank of Canada, the Bank of Montreal, the Canadian Imperial Bank of Commerce, the Bank of British Columbia, and the Bank of Nova Scotia) have made correspondence agreements with the Bank of China. Under the agreements, the five Canadian banks have opened Ren Min Bi accounts with the Bank of China in Peking, while the latter has maintained Canadian dollar accounts and, more recently, U.S. dollar accounts, with the former in Canada.

${ }^{108}$ The following payment clauses, taken from the selling and the purchasing contracts of the China National Cereals, Oils, and Foodstuffs Import and Export Corporation, provide a good example. When the Corporation is the seller, the payment clause states:

The Buyers shall establish through a bank acceptable to the Sellers a confirmed, irrevocable, assignable, divisible Letter of Credit... for the total value of the goods.... allowing $\%$ more or less both in amount and quantity at Sellers' option in favor of [the Sellers] payable/negotiable at sight against first presentation of shipping documents.

When the Chinese state corporation is the purchaser, the clause sometimes reads: "Payment against irrevocable. 96\% Letter of Credit of contract value, established through the Bank of China, 
have no control of the cargo and documents. However, as in their other business dealings, the Chinese have never failed to honor their credits. Occasionally Canadian exporters are able to persuade the Chinese to negotiate the documents in a London or Hong Kong branch of the Bank of China, in which case the exporters can retain control of the documents through their banks in London or Hong Kong until payment is assured. Of course, all of this is a question of bargaining power. An alternative protection for Canadian exporters may be the purchase of export credits insurance from either private sources or the Export Development Corporation. ${ }^{109}$

Under the Sino-Canadian Trade Agreement, trade transactions are to be settled in Canadian dollars, Chinese Ren Min Bi (RMB), or in other mutually acceptable freely convertible currencies. ${ }^{110}$ In practice, however, until 1968 all dealings between Canada and China were conducted in pounds sterling. ${ }^{111}$ Since then, an increasing number of letters of credit have been negotiated in Canadian dollars. In mid-1969, the Chinese introduced Ren Min Bi into transactions, and as a result Canadian exporters have often been asked to quote prices in that currency. At the Canton Fair the following spring the Chinese served notice that, whenever possible, all future business was to be transacted in RMB. ${ }^{112}$ These steps were taken essentially because of the devaluation of the pound sterling in 1967 and the continuing uncertainty of all major currencies. ${ }^{113}$

The Chinese attempt to use RMB as an international currency has had only limited success in Canada. At the present time, although RMB, Canadian dollars, and sterling are being used equally in Canadian imports, the Chinese currency is rarely used in Canadian export quotations. ${ }^{114}$ The main stumbling

payable on presentation of documents, $4 \%$ balance to be paid within days after discharge of goods if results of reinspection are in conformity with the stipulations of the order." A purchasing contract of another state trading corporation the author has seen is even tougher. It states that "[all] payment [is] to be made... within 30 days on arrival of the goods at Buyer's warehouse ... and after Buyer's inspection and approval."

${ }^{109}$ For a discussion of the Export Development Corporation's export credits insurance program, see Chen, Canadian Export Credits, Guarantee and Insurance Programs, in Studies In Canadian BusiNESS LAw 368, 371-81 (G. Fridman ed. 1971).

110 Trade Agreement Between Canada and the People's Republic of China, art. 5 (mimeo, Oct. 13, 1973).

111 Until recently U.S. dollars were not used in Sino-Canadian transactions because of the United States trade embargo against China which froze the dollar for use in trade with China. However, revisions of the U.S. Foreign Assets Control Regulations, effective in May of 1971, made it possible for U.S. dollars to be used in China trade. See 64 DEP'T STATE Bul.. 567-68 (1971). It was not until early 1973, however, that China actually accepted U.S. currency in trade transactions with Canada.

112 See Toronto Globe and Mail, Sept. 9, 1970, at 31, col. 4.

113 In order to facilitate the increased use of RMB, and to overcome the resistance of Canadian businessmen who prefer to deal in Canadian dollars or pounds sterling, the Chinese set a fixed exchange rate for the RMB, pegging it to the pound sterling. The Bank of China will sell RMB at the fixed exchange rate to its correspondent banks in Canada to cover payment of imports from China, and purchase from them spot RMB at the same rate in respect of proceeds of exports to China, provided evidence of a commercial contract concluded in RMB with China is shown. In addition, the Bank of China will sell and purchase "forward" RMB for a period of up to six months to cover imports from and exports to China respectively. These arrangements are contained in a letter from the London Branch of the Bank of China to its Canadian correspondents, September $29,1970$.

${ }_{114}$ According to the International Banking Office of the Bank of Montreal, since early 1973 
block is the continuing nonconvertibility of RMB in spite of its introduction into international banking transactions. ${ }^{115}$ In addition, all "forward" sales and purchases of RMB are actually effected through the Bank of China's London branch, which continues to quote in pounds sterling. The Canadian traders who contract in RMB must therefore calculate the double variable of the Canadian dollar and sterling.

\section{Warranty Clause and Commodity Inspection}

With regard to warranties of goods, there is again a striking difference between China's export and import contracts. Where the Chinese trading corporation is the buyer, the standard form contract usually places great emphasis on the warranty clause which stipulates that the seller guarantees the quantity, quality, specifications, and technical condition of the goods. This guarantee extends for a fixed period after the arrival of the goods at the port of destination or after acceptance of the goods. ${ }^{116}$ On the other hand, when China is the seller, little may be said of the guarantees in the contract. ${ }^{117}$ In view of the fact that both Chinese and Canadian law recognize the concept of implied warranties in the sale of goods, ${ }^{118}$ and that warranties inferred by law are seldom disclaimed by an exclusion clause, the lack of express warranties in most Chinese sales contracts has not presented difficult problems for Canadian buyers.

A typical Chinese buying contract would further require that the seller produce certificates of quality and quantity or weight as regards the subject goods, issued by the manufacturers or publicly-recognized surveyors. ${ }^{119}$ After arrival

U.S. dollars have also been used in a few Canadian export transactions with China.

${ }^{115}$ China permits the sale and purchase of RMB only upon evidence of a signed commercial contract concluded in RMB in order to guard against currency speculation.

${ }^{116}$ A buying contract of the China National Machinery Import and Export Corporation reads: The seller shall guarantee that the commodity is made of the best materials, with first class workmanship, brand new, unused and complies in all respects with the quality, specifications and performance as stipulated in this contract. The seller shall guarantee that the goods, when correctly mounted and properly operated and maintained shall give satisfactory performance for a period of months, counting from the date on which the commodity arrives at the port of destination.

Another contract of the same corporation says:

If prior to the completion of the warranty period of____ months after the date of final acceptance of the_[name of commodity] any defect is discovered in any part of the____ [name of commodity] which is proved to be due to defective material or workmanship, the sellers shall undertake to repair or at their option replace the defective parts.

117 None of the Chinese export contracts the author has seen contain any warranty clause expressly guaranteeing the quality of the goods.

${ }^{118}$ There is no civil code in China. However, according to a Chinese official legal textbook, it is the duty of the seller to guarantee that the goods delivered have no defects, except where the defects could have been "easily discovered" by the buyer at the time the contract was made. See Institute of Civil Law, Central Political-Judicial Cadres' School (Peking), Basic Problems in the Civil Law of the People's Republic of China 222-23 (1959) (U.S. Joint Publications Research Service, No. 4879, 1961). Similar implied warranties are set out in sections 13-16 of the Ontario Sale of Goods Act, ONT. REv. STAT. c. 421 (1970), and the acts of all other provinces.

${ }^{119}$ In the wheat agreements, such certificates are to be issued by the Canadian Grain Commission (formerly the Board of Grain Commissioners) pursuant to the Canada Grain Act, CAN. Stat. c. 7 (1970-71). The Phyto-Sanitary Certificate issued by the Plant Protection Division of the Canadian Department of Agriculture is also required. 
of the goods at the port of destination, the Chinese may apply to the China Commodity Inspection Bureau for inspection, regarding certificates issued by the Bureau as authoritative and final. ${ }^{120}$ If any discrepancies are found by the Bureau, the Chinese are entitled to one or a combination of the following remedies: (1) rejection of the goods, (2) compensation for damages, (3) replacement of defective parts, and (4) special damages for expenses incurred. Should delivery be delayed, a standard provision gives the Chinese the right to claim damages, and in case of non-delivery, the right to cancel the contract. ${ }^{121}$ Again, when the Chinese are the sellers, none of these rights are stipulated in the contracts for the protection of foreign buyers.

\section{Shipping Documents and Terms}

When the Chinese are the buyers, the foreign exporters are always required to provide detailed shipping and other documents. When the Chinese are the sellers, however, reference to shipping documents is often vague, if not omitted altogether. ${ }^{122}$ Furthermore, when the Chinese are the importers, transshipment is specifically prohibited, whereas when they are the exporters,

${ }^{120}$ On the power of the China Commodity Inspection Bureau, see Hsiao, Communist China's Foreign Trade Organization, 20 VAND. L. REv. 303, 309-10 (1967).

${ }^{121}$ See, e.g., the inspection and claims clause found in a standard form contract in which the China National Cereals, Oils, and Foodstuffs Import and Export Corporation is the buyer. The clause stipulates:

(1) Goods under this order are contracted on basis of landed quality and landed weight, with certificate issued by the China Commodity Inspection Bureau as final. (2) The goods purchased under this order shall be subject to the inspection by the China Commodity Inspection Bureau at the port of destination. Should the quality, specifications, quantity and/or weight be found not in conformity with the stipulations of the order, due to causes other than those for which the Insurance Company or Shipping Company are liable, the Buyers shall on the strength of the Survey Report issued by the aforesaid Bureau have the right to reject the goods delivered and/or to file claim against the Sellers, with the survey fees for the Sellers' account. The time for inspection and claim should be within__days after discharge of the goods. (3) If results of reinspection are not in conformity with the stipulations of the order, the Buyers have the right to deduct their.claim from $4 \%$ balance [unpaid by the Buyers]. In case amount claimed exceeds $4 \%$ balance, then the difference is to be remitted by the Sellers. (4) In the event of the Sellers' failing to make delivery effect shipment within the stipulated time, unless caused by Force Majeure as specified below, the Buyers shall have the right to cancel the order and withdraw the Letter of Credit, if opened, and in such case the Sellers shall reimburse the Buyers for all the losses and expenses incurred directly attributable to the non-delivery/non-shipment.

${ }_{122}$ When the China National Cereals, Oils, and Foodstuffs Import and Export Corporation is the buyer, a contract clause specifies in detail the documents required:

1. Full set of negotiable clean on board ocean bills of lading marked "freight payable at destination" [i.e., when f.o.b. contract] or "freight prepaid" [i.e., when c.i.f. contract]. 2. Signed invoice indicating order number. 3. Weight memo. 4. Quality certificate and weight certificate issued by manufacturers or publicly-recognized surveyors. 5. Copy of cable advice of shipment/dispatch. 6. Steamship company's scheduled itinerary evidencing that the carrying vessel, prior to her arrival at the port of destination, shall not call at U.S.A. ports and Taiwan. 7. A letter certifying that all the copies of the required documents have been sent to us by airmail. 8 . Insurance policy or certificate. 9 . Steamship company's letter undertaking shipment to the destination without any transshipment. (Emphasis added.) Compare the following clause, which is couched in vague and general terms. It is taken from a standard form contract employed when the China National Light Industrial Products Import and Export Corporation is the seller.

Immediately after the signing of this Contract or punctually as otherwise mutually agreed upon, the Buyers shall establish the required Letter of Credit allowing transshipment and partial 
the shipping conditions always allow them transshipment and partial shipment. ${ }^{123}$

About fifty per cent of shipments from China to Canada are direct from Chinese ports to Vancouver. ${ }^{124}$ The remainder are transshipped from Hong Kong, Rotterdam, or Kobe, Japan, ${ }^{125}$ depending upon whether the goods are destined for the east or west coast of Canada. The delay caused by transshipment has deterred Canadian importers because of the lengthened turnover period for capital and the probable loss of sale in seasonal markets.

As previously mentioned, for both import and export the Chinese prefer to handle shipping themselves in order to save hard currency. In China this responsibility belongs to the Chinese National Chartering Corporation, which maintains a large fleet of chartered vessels as well as a growing number of its own to work between Chinese and Canadian ports. In the charter parties concluded by the China National Chartering Corporation, a typical clause stipulates that the vessels used shall not call at U.S. ports and shall not be in the vicinity of Taiwan. ${ }^{126} \mathrm{~A}$ similar clause can also be found in the rare $c$. \& $\mathrm{f}$. or c.i.f. sales to China, when foreign traders assume responsibility for shipping. ${ }^{127}$ In view of the dramatic change in United States-Chinese relations from hostility to normality, ${ }^{128}$ and the easing of U.S. restrictions on American-owned vessels which seek to call at Chinese ports, ${ }^{129}$ the above-mentioned clause prohibiting vessels used in China trade from visiting U.S. ports may be expected to disappear from the Chinese standard form contracts soon.

\section{E. Force Majeure}

All Sino-Canadian trade contracts have force majeure clauses, though their precise meaning is not always clear. Many of these clauses do not contain elaborate definition; ${ }^{130}$ others provide that the sellers shall not be liable for non-

shipment in favor of the Sellers through the Bank of China, or their Correspondents, of a first class Bank [whatever this may mean] who can authorize the negotiation in China and will reimburse the PAYMENT AGAINST SHIPPING DOCUMENTS AT SIGHT. The Buyers shall so arrange that the relative Letter of Credit will reach the Sellers with an allowance of at least 4-8 weeks before the time of shipment designated. (Emphasis added.) ${ }^{123} I d$.

${ }^{124}$ See Stark, An Analysis of the Foreign Trade Practices of the People's Republic of China Including Comments on the Canadian Experience, 5 U.B.C.L. REv. 165, 182 (1970).

${ }_{125}$ According to a Vancouver importer, transshipment at Kobe has created special problems of delay. After the first carrying vessel from China discharges. goods at the Japanese port, the shipment is frequently held up by Japanese shipping companies because they prefer to wait for one of their own vessels rather than take the next available vessel to Vancouver.

${ }^{126}$ One charter party stipulates that "when ordered for Shanghai or North China discharge, vessel to proceed at least 60 miles east of Taiwan."

${ }^{127}$ See the contract clause of the China National Cereals, Oils, and Foodstuffs Import and Export Corporation, supra note 120.

${ }^{128}$ In a joint communique dated February 22, 1973, the United States and China agreed to establish a "liaison office" in each other's capital. Although the agreement does not establish full diplomatic relations, it authorizes the creation of a diplomatic presence of unlimited size in both capitals, with diplomatic immunity for the members of both missions, and "a concrete program of expanding trade as well as scientific, cultural, and other exchanges." See N.Y. Times, Feb. 23, 1973, at 1, col. 8.

12931 C.F.R. $\S \S 500.538,500.541 ; 36$ Fed. Reg. 8584 (1971).

130 For example, the force majeure clause in a purchasing contract prepared by the China Metals 
delivery or delay caused by "war, flood, fire, storm, heavy snow, or other causes beyond sellers' control."131

Whether the term "other causes beyond sellers' control" found in the force majeure clauses includes strikes and other labor disputes, is unclear from the contracts. Experience shows, however, that whenever suggested by Canadian negotiators, the Chinese have invariably refused to consider inclusion of strikes in the language of the force majeure clauses. It would be altogether surprising if a Marxist-Leninist who considers a strike as an inherent vice of the capitalist system were willing to share the resulting loss with the capitalist exporters. ${ }^{132}$

None of the force majeure clauses are explicit as to whether a change in Chinese foreign trade plans or the cancellation of export or import licenses by the Chinese Ministry of Foreign Trade would excuse a Chinese state trading corporation from contract obligations. Like Soviet law, ${ }^{133}$ however, Chinese law considers Chinese sellers' contractual obligations extinguished if the impossibility of performance is caused by a change of law or by a governmental shift in economic planning. ${ }^{134}$ The same principle may not apply to exonerate foreign sellers from legal impossibility for, in some contracts where the Chinese are the buyers, the force majeure clauses stipulate that the "[foreign] sellers" inability in obtaining export license shall not be considered as Force.Majeure."135

When force majeure is claimed, the Chinese generally insist on a clause requiring the seller to notify the buyer immediately. Within a stipulated period of time, the seller must provide the buyer with satisfactory proof of the cause and nature of the circumstances of force majeure. Thus the contract obligation will be altered accordingly and, in some cases, may be cancelled by the buyer. ${ }^{\mathbf{1 3 6}}$

and Minerals Import and Export Corporation simply states that "[i]n case of Force Majeure the Sellers shall not be held responsible for delay in delivery or non-delivery of the goods....."

${ }^{131}$ For example, a China Cereals, Oils, and Foodstuffs Import and Export Corporation's sales contract stipulates:

Should the Sellers fail to deliver the contracted goods or effect the shipment in time by

the reason of war, flood, fire, storm, heavy snow or any other causes beyond their control, the

time of shipment might be duly extended, or alternatively a part or whole of the contract

might be cancelled, but the Sellers have to furnish the Buyers with a certificate attesting

such event or events. (Emphasis added.)

132 See generally Pan American World Airways, Trade With China 69 (1971).

${ }^{133}$ See Berman, Excuse for Nonperformance in the Light of Contract Practices in International Trade, 63 Colum. L. Rev. 1413, 1436 (1963); Berman, Force Majeure and the Denial of an Export License Under Soviet Law: A Comment on Jordan Investments Ltd. v. Soiuznefteksport, 73 HARv. L. Rev. 1128 (1960); Domke, The Israeli-Soviet Oil Arbitration, 53 AM. J. INT'L L. 787 (1959). See also S. PISAR, Coexistence and Commerce: Guidelines for Transactions Between East and West 274-79 (1970).

${ }^{134}$ According to the Chinese Institute of Civil Law, "[i]nsofar as the obligation resulting from a Chinese governmental planning document is concerned, the plan is the premise on which the obligation is created, and the obligation, in turn, is a means to insure the fulfiliment of the plan. Therefore, when the planning document is rescinded, the obligation is also extinguished." Institute of Civil Law, Central Political-Judicial Cadres' School (Peking), Basic Problems in the Givil Law of THE People's Republic of China 191 (1959) (U.S. Joint Publications Research Service, No. 4879, 1961). See also Pfeffer, The Institution of Contracts in the Chinese People's Republic, China Q., July-Sept. 1963, at 115, 134-35.

${ }_{135}$ The quotation is taken from a standard form contract in which the China National Metals and Minerals Import and Export Corporation is the buyer.

${ }^{136}$ For example, in a contract where the China National Cereals, Oils, and Foodstuffs Import and Export Corporation is the buyer, the force majeure clause stipulates that: 


\section{F. Penalty Clause}

While the penalty clause is seldom found in contracts where the Chinese are the sellers, it is the deterrent most favored by the Chinese as a means of enforcing delivery when they are the buyers. For example, in a current contract where the China National Machinery Import and Export Corporation is the buyer, unless the excuse of force majeure can be claimed, a penalty will be imposed on the Canadian seller for delayed delivery at the rate of 0.5 per cent of the value "for each of the first three months after ... one month grace and 1.0 per cent per month thereafter." As in most contracts, a penalty ceiling of $\mathbf{5 . 0}$ per cent of the total value of the contract is stipulated.

It should be noted that the penalty clause employed in Chinese trade contracts does not fall within the common law meaning of the term. Having been borrowed from the Soviet experience, which is clearly different from the common law, the penalty clause under Chinese law serves both deterrent and quasi-compensatory functions. To a socialist society, a breach of contract frequently results in a breach of the state plan. Punishment is, therefore, considered appropriate both to vindicate society's interest and to assure maximum efforts in fulfillment of that interest. Where the obligee suffers damages less than the amount of the penalty, the penalty itself is compensatory to the extent of the damages. In the event the penalty amount does not cover the damages suffered, the obligee can recover compensatory damages to make up the difference. ${ }^{137}$

\section{G. Settlement of Commercial Disputes ${ }^{138}$}

In 1954 and 1958, respectively, China established the Foreign Trade Arbitration Committee and the Maritime Arbitration Committee, under the aegis of the China Council for the Promotion of International Trade, for the purpose of settling foreign trade disputes by arbitration. ${ }^{139}$ However, because of the traditional Chinese distaste for adjudication, the Chinese foreign trade corporations prefer negotiation as a means of dispute settlement, reserving arbitration only as the last resort. ${ }^{140}$ Thus, most Chinese foreign trade contracts

\footnotetext{
In case of delayed delivery/shipment due to force majeure such as war, serious flood, fire, frost, ice or other natural calamities, the Sellers shall immediately advise the Buyers by cable of the occurrence, and within 15 days thereafter airmail to the Buyers a certificate evidencing such accident/incident to be approved by the Buyers. Under such circumstances, the Sellers, however, are still under obligation to take all necessary measures to hasten the delivery of the goods so delayed; in case the accident/incident lasts for more than eight weeks, the Buyers shall have the right to cancel the Order.

${ }^{137}$ For an analysis of the legal nature of penalty clauses in Chinese law, see Pfeffer, supra note 134 , at $129-31$.

${ }_{138}$ See generally McCobb, Foreign Trade Arbitration in the People's Republic of China, 5 N.Y.U.J. Int'l L. \& Pol. 205 (1972). See also 3 International Commercial Arbitration 126-35 (P. Sanders ed. 1965).

139 For the structure and procedure of the Chinese arbitration organs, see Hsiao, Communist China's Foreign Trade Organization, 20 VAND. L. REv. 303, 314-17 (1969); Hsiao, Communist China's Foreign Trade Contracts and Means of Settling Disputes, 22 VAND. L. REv. 503, $511-18$ (1969).

${ }_{140}$ See Cohen, Chinese Mediation on the Eve of Modernization, 54 Calif. L. REv. 1201 (1966); Lubman, Mao and Mediation: Politics and Dispute Resolution in Communist China. 55 Calif. L. Rev. 1284 (1967). See generally D. Bodde \& C. Morris, Law in Imperial. China (1967).
} 
contain an arbitration clause, and where such a clause is included it always commences: "Any dispute in connection with the execution of this contract shall be settled through friendly negotiation. Failing such settlement all disputes shall be submitted for arbitration."141

When arbitration is to take place, there are several different types of clauses with respect to the location of the hearing and to the rules of procedure applicable. The Chinese naturally prefer that arbitration take place in Peking and that their own rules of procedure apply. Thus, in their contract negotiations with foreign traders the Chinese have invariably proposed that disputes be arbitrated by their arbitration organizations. It is generally conceded that the Chinese arbitration procedures and awards are fair, and that their panels of arbitrators (which are made up exclusively of Chinese nationals) are professionally competent. Yet very little is known to the outside world regarding the procedure actually employed and the substantive law applied when the arbitration takes place in Peking. ${ }^{\mathbf{1 4 2}}$ Moreover, the intimate interconnections of the Chinese arbitration organs with the Ministry of Foreign Trade and the state trading corporations cast some doubt on their impartiality. ${ }^{143}$ All this explains the reluctance of many Canadian firms to accept arbitration in China. In view of the bargaining leverage on the Chinese side, however, Canadian companies frequently acquiesce to provisions for arbitration by the Chinese organizations. ${ }^{144}$

As an alternative to arbitration in China by the Chinese arbitration organizations, the Chinese have sometimes agreed to a formula whereby arbitration may take place in the country of the defendant. Thus, a sales contract of the China National Cereals, Oils, and Foodstuffs Import and Export Corporation may contain the following clause:

[A]rbitration... shall take place in the country where the defendant resides. Each party shall appoint an arbitrator, the two arbitrators thus appointed shall select a third person as chairman to form an arbitration committee. In case the claim is made on the Chinese Party, the arbitration shall be held by the Foreign Trade Arbitration Committee of the China Council for the Promotion of International Trade in accordance with the Provisional Rules of the Procedure of the ... Committee. ${ }^{145}$

\footnotetext{
141 The 1967 wheat agreement concluded between the Canadian Wheat Board and the China National Cereals, Oils, and Foodstuffs Import and Export Corporation does not contain an arbitration clause for dispute settlement, yet it requires that, in case of dispute, "the Sellers undertake to negotiate with the Buyers an amicable settlement in respect of any loss sustained."

${ }_{142}$ As of this time, China has not yet enacted a written code of commercial law or rules of private international law, and has not published either judicial or arbitral decisions or scholarly studies on the subjects. See Cohen, Chinese Law and Sino-American Trade, in China Trade Prospects AND U.S. Policy 127, 164 (A. Eckstein ed. 1971).

${ }^{143}$ See note 139 supra.

144 Thus, the most frequently found arbitration clause in a Sino-Canadian trade contract contains the provision that "the case [in dispute] shall be referred to the Foreign Trade Arbitration Committee [or the Maritime Arbitration Committee] of the China Council for the Promotion of International Trade in Peking for arbitration according to the provisional rules of procedure of the Council. ..."

${ }^{145}$ A similar clause contained in the uniform general charter of the China National Chartering Corporation simply states that "the dispute shall ... be referred to arbitration in Peking or London, in Defendant's option."
} 
This clause specifically designates China's Foreign Trade Arbitration Committee as the arbitration organization in the event of arbitration in China, but no counterpart is named if arbitration is to take place outside China. This will invariably result in arbitration exclusively by Chinese arbitrators if arbitration is to take place in China, because the members of China's Foreign Arbitration Committee are all of Chinese nationality. ${ }^{146}$ However, if arbitration is to be in a foreign country, there is no similar assurance that the arbitrators will all be fellow nationals of the foreign defendant. In this sense, the clause seems to favor the Chinese side. In addition, it could lead to complicated maneuvering by the parties to ensure designation as defendant, rather than as plaintiff, in the arbitration proceedings.

Occasionally, Sino-Canadian trade contracts have called for arbitration in a third country agreeable to both parties. This is especially true when the contracts involve export of capital equipment to China. In such sales, the Canadian firms have often insisted on such an arbitration clause because the complexity of the goods tends to foster disputes. As a result of their strong bargaining position in this area, they have generally been permitted to have their way. Thus, a recent multi-million dollar contract for the supply of electronic equipment by a leading U.S. subsidiary company in Canada to the China National Machinery Import and Export Corporation contained the following clause:

Each party shall appoint an arbitrator within 30 days after receipt of notification from the opposite party and the two arbitrators thus appointed shall jointly nominate a third person of Swedish nationality as umpire to form an arbitration committee. The arbitrators shall be confined to persons of Chinese and American nationality.... The arbitration shall take place in Stockholm, Sweden, in accordance with the Swedish Arbitration Procedures and with reference to the Swedish Arbitration Laws. ${ }^{147}$

This approach assures impartial arbitration, but it has the potential drawback of placing the dispute before an arbitration tribunal whose rules and procedures are unfamiliar to both parties. In one contract with Canadian traders, the Chinese are known to have agreed to an arbitration clause designating the Arbitration Court of the International Chamber of Commerce in Paris as the arbitration tribunal and its rules as the governing law of procedure.

Unlike those contained in the contracts between Western firms, none of the arbitration clauses found in the China trade contracts stipulate the substantive law to be applied by the arbitrators. Since China does not seem to have enacted rules of private international law, it is difficult to determine what legal system is to govern the contract. Wherever the arbitration may take place, if the tribunal considers Chinese law the proper law of the contract, the foreign firms will still be in a vulnerable position because law and procedures in China governing

\footnotetext{
${ }^{146}$ See note 142 supra.

147 The arbitration clause limits the choice of arbitrators to those of "Chinese and American nationality" because the contract was negotiated and executed by the Canadian firm's parent company, although the goods were supplied by the Canadian firm.
} 
export and import activities are in a rudimentary state. ${ }^{148} \mathrm{It}$ is extremely difficult to predict with confidence the legal position of the parties. The solution may be for the parties to anticipate the substantial issues which might arise during the performance of the contract, and then to fix their own law in the contract.

Another problem concerns the enforcement of arbitration clauses. Neither Canada nor China adheres to any multinational arbitration conventions, such as the Geneva Protocol on Arbitration Clauses of $1923,{ }^{149}$ the Convention on the Execution of Foreign Arbitration Awards of $1927,{ }^{150}$ or the United Nations Convention on the Recognition and Enforcement of Foreign Arbitration Awards of 1958..$^{151}$ Nor is there a bilateral treaty providing for the enforcement of arbitration agreements and of awards in disputes between nationals of the two countries.

The laws of both countries are silent as to whether an agreement to arbitrate an existing or future foreign trade dispute is enforceable. In view of the Chinese policy favoring arbitration of foreign trade disputes, such an agreement would seem to be enforceable by Chinese courts. ${ }^{152}$ In the common law provinces of Canada, enforcement is also possible by the indirect use of an application to stay litigation brought in violation of an agreement to arbitrate. ${ }^{153}$ In Quebec, however, only the agreement to arbitrate an existing and actual dispute (compromis) is enforceable; a promise to arbitrate a future dispute (clause compromissoire) is not. ${ }^{154}$

${ }^{148}$ See note 142 supra.

14927 L.N.T.S. 157 (1924).

15092 L.N.T.S. 301 (1927).

151330 U.N.T.S. 38. The Convention was opened for signature on June 10, 1958. For a discussion of the Convention, see Springer, The U.N. Convention on the Recognition and Enforcement of Foreign Arbitral Awards, in American Arbitration Association, New Strategies for Peaceful Resolution of International Business Disputes 25-26 (1971).

${ }^{152}$ See Li, Legal Aspects of Trade With Communist China, 3 Colum. J. Transnat'L L. 57, 67 (1964). ${ }^{153}$ The nine common law provinces have almost identical legislation. Section 7 of the Ontario Arbitration Act, ONT. Rev. Stat. c. 25 (1970), which is typical, reads as follows:

If a party to a submission, or a person claiming through or under him, commences any legal proceeding in any court against any other party to the submission, or any person claiming through or under him, in respect of any matter agreed to be referred, any party to such legal proceeding may at any time after appearance and before delivering any pleading or taking any other step in the proceeding apply to that court to stay the proceeding and a judge of that court, if satisfied that there is no sufficient reason why the matter should not be referred in accordance with the submission and that the applicant was at the time when the proceeding was commenced and still remains ready and willing to do all things necessary to the proper conduct of the arbitration, may make an order staying the proceeding. The word "submission" is defined in section 1(d) as "a written agreement to submit present or future differences to arbitration, whether or not an arbitrator is named therein." The court has complete discretion as to whether to stay the action. In most cases stays are granted. In fact, where there is a submission to a foreign arbitration tribunal, the case for a stay may well be stronger than if a domestic arbitration agreement were involved. See Planned Sales, Ltd. v. Einson-Freeman International (Americas), Ltd., [1955] Ont. W.N. 443, 447 (H. Ct. 1955); Kennedy, Ltd. v. Fiat, [1923] Ont. W.N. 537 (S. Ct. 1923). But cf. A. S. May Co., Ltd. v. Robert Reford Co., Ltd., 6 D.L.R.3d 288 (Ont. H. Ct. 1969).

${ }^{154}$ In a recent decision in Borenstein v. Trans-American Investment \& Development Co. Ltd. \& Langenauer, [1970] C.S. 192, the Quebec Superior Court held that a contract clause requiring the parties to submit all disputes to "final and binding arbitration" was against public order and unenforceable. Cf. Brierley, Aspects of the Promise to Arbitrate in the Law of Quebec, 30 R. DU B. 473 (1970); Colas, Clause compromissoire, compromis et arbitrage en droit nouveau, 28 R. DU B. 129, 133 
As to the enforcement of arbitration awards, all Sino-Canadian trade contracts stipulate that the awards given "shall be final and binding upon both parties." The same provision is also found in the Chinese arbitration rules which, moreover, prohibit the parties to "bring an appeal for revision before a court of law or any other organization."155 In China, therefore, the arbitration award rendered by Chinese arbitration committees must be executed by the parties within the time fixed by the award, otherwise one of the parties may petition the court to enforce it. ${ }^{156}$ The fate of foreign arbitration awards in Chinese courts is nevertheless uncertain. Considering again the Chinese policy favoring arbitration as a means of settling foreign trade disputes, it seems likely that the Chinese courts would also enforce foreign awards. In practice, however, no question about the enforcement of an award, Chinese or otherwise, has ever arisen. As in China, a foreign trade arbitration award, whether rendered locally or otherwise, is enforceable in all Canadian provinces upon obtaining leave from a Canadian court having jurisdiction. ${ }^{157}$ An arbitration award that has been made enforceable by a foreign judgment may also be enforced in Canada as a judgment. ${ }^{158}$

Despite the widespread adoption of arbitration clauses in Sino-Canadian contracts, there is no record of any arbitration between Canadian firms and the Chinese. ${ }^{159}$ The very few reported disputes have all been resolved amicably by direct negotiations between the parties. ${ }^{160}$ This is not surprising, as Canadian businessmen who are invariably anxious to establish a foothold in the China markets tend to be rather cautious and conciliatory in dealing with the Chinese, and the latter, in turn, are known for their honesty and scrupulousness in international transactions.

(1968); Kos-Rabcewicz-Zubkowski, Arbitration in the Code of Civil Procedure of Quebec, 3 R.J.T. 143, 159 (1968); Toth, in Lectures, Bar of the Province of Quebec, The Code of Civil Procedure 141 (1966); Tyndale, Notes on the New Code of Civil Procedure, 26 R. Du B. 345,359 (1966).

${ }^{155} \mathrm{See}$ article 31 of the Provisional Rules of Procedure of the Foreign Trade Arbitration Committee (FTAC), in Trade Wrth China, A Practical Guide 98-104 (1957), and article 33 of the Provisional Rules of the Maritime Arbitration Committee (MAC), in 3 International Commercial Arbitration 138-41 (P. Sanders ed. 1965).

${ }^{156} \mathrm{See}$ article 32 of the Provisional Rules of Procedure of the Foreign Trade Arbitration Committee (FTAC), in Trade With China, A Practical Guide 98-104 (1957), and article 32 of the Provisional Rules of Procedure of the Maritime Arbitration Committee (MAC), in 3 InTERnational. Commercial Arbitration 138-41 (P. Sanders ed. 1965).

${ }^{157}$ See, e.g., section 13 of the Ontario Arbitration Act which says that "[a]n award may, by leave of a judge, be enforced in the same manner as a judgment or order to the same effect." In Quebec, however, a normal court action has to be instituted for this purpose. See Quebec Code of Civil Procedure $\$ 950$ (1966). For a discussion of the enforcement of foreign arbitration awards in Canada, see Castel, Recognition and Enforcement of Foreign Judgments in Personam and in Rem in the Common Law Provinces of Canada, 17 Mc GILl L.J. 11, 183-88 (1971); Kos-Rabcewicz-Zubkowski, supra note 154, at 152-56.

158 Thus, in Stolp \& Co. v. Browne \& Co., 66 Ont. L.R. 73, 38 Ont. W.N. 400, 4 D.L.R. 73 (Ont. S. Ct. 1930), noted in 12 CAN. B. Rev. 259 (1934), the Supreme Court of Ontario held that a foreign judgment pursuant to a foreign arbitration award may be enforced in Ontario by action.

159 According to Fellhauer, however, among the 61 cases arbitrated by the Chinese arbitration committees as of 1960, some did involve Canadian parties. See H. Fellhauer, Foreign Trade Arbitration Jurisdiction in THE P.R.C. 6 (U.S. Joint Publication Research Service, No. 8612, 1961).

${ }^{160}$ The well-publicized complaint by the Chinese against the Canadian Wheat Board in November of 1970 concerning infested grain allegedly delivered was quickly and amicably settled pursuant to an agreement by the parties to readjust the prices. See Edmonton Journal, Nov. 9, 1970 , at 1 , col. 1 . 


\section{ConClusion}

The legal institutions governing Canada's trade with China do not differ greatly in their fundamental features from those involving other countries. The incompleteness of China's formal domestic legal system and its lack of either a civil or commercial code make it difficult, if not impossible, to predict or discuss technical legal aspects of China's foreign trade, such as the problems concerning letters of credit, force majeure, and choice of law, ${ }^{161}$ but this has presented no significant obstacle to Sino-Canadian trade. In fact, as an international trader, China offers a comparatively risk-free market. The existing legal framework governing Sino-Canadian trade, although it might well be improved, seems to be adequate for present purposes, and may well prove to be a promising model for future Sino-American trade.

In international trade, law is not an end but a technique to achieve certain economic and political goals. In the final analysis, therefore, actual expansion of trade depends primarily upon political and economic factors. Because Canada was the first major Western nation to recognize China after French recognition in 1964, and because Canada played an important role in helping China win its seat in the United Nations, many Canadians have felt that Canada has a preferred position politically. ${ }^{162}$ This feeling may prove to be only partly justified. In view of the slight success of Canadian traders, as compared to British, French, and Japanese firms selling technological products to the Chinese, ${ }^{163}$ economic considerations may still take priority over political considerations in China's international trade. Economically, Canada and China are essentially competitive, rather than complementary. Canada can supply a wide range of highly technological products and services to China, ${ }^{164}$ but there is not much Canada can import from China. As the balance of trade between the two countries has already shifted drastically to one side as a result of the wheat sales, there are only modest prospects of a significant increase in SinoCanadian trade beyond the current level.

\footnotetext{
${ }^{161}$ For a first hand report of the current status of Chinese foreign trade law, see Cohen, Report from China: Chinese Law at the Cross Roads, China Q., Jan.-Mar. 1973, at 139, 142-43.

${ }^{162}$ See generally Importers' Bull., Nov. 14, 1973.

${ }^{163}$ See Burns, Trudeau Seeking to Strengthen Trade With China in Areas Other Than Wheat, Toronto Globe and Mail, Oct. 11, 1973, § B, at 4, col. 3.

${ }^{164}$ For example, Canada's expertise in building railroads, its experience in the exploring, mining and processing of metals, oils, and gas, its supply of a whole range of wood products including low-cost prefabricated buildings, and its supply of turn-key fertilizer, synthetic rubber, and other chemical plants. See Modak, China and the Pacific Rim Community, ExecuTIve, Apr. 1973, at 22, 24.
} 